\title{
EXPRESSION OF THE Tn ANTIGEN ON ERYTHROID CELLS FROM A PATIENT WITH Tn SYNDROME
}

\author{
Yoko Kamitani, ${ }^{1}$ Eiji KaJII, ${ }^{1}$ Toshio Suda, ${ }^{2}$ \\ and Shigenori IKEмото ${ }^{1}$ \\ ${ }^{1}$ Department of Legal Medicine and Human Genetics; and \\ ${ }^{2}$ The Division of Hematology, Department of Medicine, Jichi Medical School, \\ Kawachi-gun, Tochigi 230-04, Japan
}

\begin{abstract}
Summary In order to examine expression of the Tn antigen on erythroid cells from a patient with Tn syndrome, we applied a selective two phase liquid culture system for human erythroid progenitors in peripheral blood. The cells were analyzed with flow cytometry employing an anti-Tn antibody and a lectin of Vicia villosa which recognizes only the Tn determinant. In the second phase, the Tn antigen was expressed on the cultured cells from the patient on day 3 and Tn-positive cells reached $62.7 \%$ on day 9. On the other hand, Tn-positive cells were not detected in the volunteer's cultured cells. When the patient's cells were co-cultured with the cells from a healthy volunteer, the percentage of Tn-positive cells was much lower than the expected value, suggesting that the normal cells suppressed the expression of Tn antigen on the patient's cells.
\end{abstract}

Key Words Tn antigen, erythroid cells, liquid culture, refractory anemia

\section{INTRODUCTION}

The Tn syndrome is an acquired clonal disorder characterized by the exposure of a normally hidden determinant, the Tn antigen, on the surface of human erythrocytes, platelets, granulocytes, and lymphocytes (Bird et al., 1971; Vainchenker et al., 1985). This disorder may be associated with a mild hemolytic anemia, leukopenia, or thrombocytopenia, but has also been described in some acute leukemias or myeloproliferative diseases (Bird et al., 1976; Baldwin et al., 1979; Ness et al., 1979; Vainchenker et al., 1985). The biochemical basis of Tn activation is now well characterized and corresponds to the exposure of an $\mathrm{N}$-acetylgalactosamine residue carried by cell surface glycoproteins, which arises from a selective loss of

Received August 7, 1992; Revised October 5, 1992. 


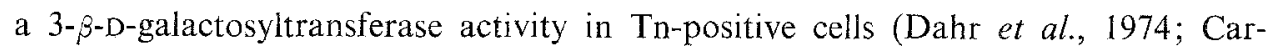
tron et al., 1978a, 1978b, 1979).

On the developmental expression of the Tn antigen in the various blood cells, there has been little research, because a sequential system suitable for obtaining undifferentiated and differentiated cells has not been available. However, recently, Fibach et al. (1989, 1990) and we (Wada et al., 1990) have reported a new method of a two phase liquid culture system for human erythroid progenitors existing in the peripheral blood. This culture system is useful for studying not only the erythroid differentiation but also the expression of various blood group antigens in erythroid progenitors (Wada et al., 1990). By using the two phase liquid culture system for peripheral blood mononuclear cells from a patient with a typical Tn syndrome, the development and expression of the $\mathrm{Tn}$ antigen on erythroid cell membranes were analyzed sequentially. In order to define possible mechanisms for the expression of the Tn antigen, a mixed culture of the mononuclear cells from the patient and a healthy volunteer was performed, and we clarified whether the expression of $\mathrm{Tn}$ antigen was suppressed by normal cells.

\section{MATERIALS AND METHODS}

Patient. A 55-year-old Japanese man was admitted to Tottori Prefectural Central Hospital in May 1990 because of a bleeding tendency. Admission laboratory data were: hemoglobin $11.9 \mathrm{~g} / \mathrm{dl}$, erythrocytes $3.91 \times 10^{6} / \mu \mathrm{l}$, reticulocyte count $1.9 \%$, white blood cells $1,400 / \mu$, platelets $18,000 / \mu$. The counts of blasts in the peripheral and bone marrow blood were 1.0 and $9.0 \%$, respectively. The number of blasts and morphological abnormalities detected in the myeloid series, erythroblasts, and platelets corresponded with those of refractory anemia with excess of blasts (RAEB) in myelodysplastic syndrome (MDS) of FAB classification (Bennett et al., 1982, 1985). The erythrocytes were agglutinated with monoclonal anti-H, but not with monoclonal anri-A or anti-B antibody. The sera contained anti-A and anti-B antibodies. Originally the ABO-blood group system was typed as group $O$. The patient had received no blood transfusions until this admission. The erythrocytes were polyagglutinable and strongly agglutinated with extracts from Dolichos biflous, Salvia sclarea, Vicia villosa, and Helix pomatia, but unreactive with hexadimethrine bromide (Polybrene), Arachis hypogaea, and cord serum (as seen in Results). The direct and indirect antiglobulin tests were negative.

These data indicated expression of the Tn antigen on the erythrocytes. In addition, flow cytometric analyses revealed the Tn antigen on platelets, granulocytes, monocytes, and lymphocytes. Accordingly, the diagnosis of Tn syndrome associated with RAEB was made.

Cells. Heparinized whole blood was drawn from the cubital veins of the patient with the Tn syndrome and unrelated healthy volunteers after informed consent. Using $15-\mathrm{ml}$ plastic tube, $7.5 \mathrm{ml}$ of the whole blood was centrifuged over 
$4.5 \mathrm{ml}$ Ficoll-Conray medium (Immunobiological Laboratories, Fujioka) in each tube at $500 \mathrm{~g}$ for $30 \mathrm{~min}$ at the room temperature. After centrifugation, the mononuclear cells were harvested from the interfaces, pooled and washed twice with Iscove's modified Dulbecco's medium (IMDM; GIBCO Laboratory, Grand Island, NY). The erythrocytes from the lower layer were washed three times in isotonic saline solution.

Lectins. D. biflorus and S. sclarea were purchased from Sanko Junyaku Co. (Tokyo). Fluorescein isothiocyanate (FITC)-labeled $V$. villosa was purchased from Sigma Chemical Co. (St. Louis, MO). S. sclarea, H. pomatia, and A. hypogaea were purchased from E-Y Laboratories, Inc. (San Mateo, CA). These lectins were used according to the manufactures' instructions.

Production of polyclonal anti-Tn antibody. About $4.5 \times 10^{9}$ Tn-positive erythrocytes diluted in $5 \mathrm{ml}$ of saline were injected three times into the ear vein of a rabbit every 5 days. Then, the serum prepared from the immunized rabbit was tested for production of anti-Tn.

Hemagglutination tests. Various lectins and the sera from the rabbit were used for the hemagglutination tests according to the technical manual of the American Association of Blood Banks (Widman, 1985). As for the test procedure, 40 $\mu 1$ of $2 \%$ erythrocyte suspensions were mixed with $40 \mu l$ of the lectins or sera in a test tube and incubated for $30 \mathrm{~min}$ at $37^{\circ} \mathrm{C}$. Hemagglutinations were observed after centrifugation for $1 \mathrm{~min}$ at $300 \mathrm{~g}$.

Absorption tests. The procedure was performed according to the technical manual of the American Association of Blood Banks (Widman, 1985). One volume of Tn-negative or Tn-positive erythrocytes was added to the same volume of serum from the immunized rabbit and incubated for $2 \mathrm{hr}$ at $37^{\circ} \mathrm{C}$ and then overnight at $4^{\circ} \mathrm{C}$. After incubation, the suspension was centrifuged for $5 \mathrm{~min}$ at $1,000 \times \mathrm{g}$. The ability of the supernatants to agglutinate erythrocytes of various phenotypes was then tested.

Dimercaptoethanol (2ME)-treatment. The treatment was performed according to the method of Mollison (1983). Briefly, $50 \mu \mathrm{l}$ of a $2 \mathrm{ME}$ (Wako Pure Chemical Ind., Osaka) were incubated with the equivalent volume of serum for 2 hr at $37^{\circ} \mathrm{C}$, after which hemagglutination tests were conducted on the Tn-positive erythrocytes.

High pressure liquid chromatography (HPLC). In order to assess the activity of the anti-Tn antibody in the serum, HPLC analysis was performed by using a model 342 gradient liquid chromatographic system (Beckman Instruments Inc., Berkeley, CA) with a TSK-GEL 3000 SW column (Toyo Soda, Tokyo) according to the method of Kamesaki et al. (1989). The system included a $114 \mathrm{M}$ pump, a loop-type $21 \mathrm{~A}$ injector, and a model $1600 \mathrm{UV}$ variable wave length detector operated at $280 \mathrm{~nm}$. The eluent was a phosphate buffer $(0.1 \mathrm{M}, \mathrm{pH} 6.5)$ and $0.3 \mathrm{M} \mathrm{NaCl}$ and the injection volume was $100 \mu 1$. The molecular weight markers were obtained from Bio-Rad Laboratories (Richmond, CA). 
Liquid culture system. Experiments were carried out by a liquid culture according to our method (Wada et al., 1990). The procedure was divided into two phases. Mononuclear cells were suspended in IMDM with $10 \%$ fetal calf serum (FCS; Flow Laboratories, North Ryde, NSW, Australia) and 5\% phytohemagglutinin-stimulated leukocyte conditioned medium (PHA-LCM) which was prepared as described previously (Suda et all, 1985). Then the cells were incubated at $1 \times$ $10^{6} / \mathrm{ml}$ in $25 \mathrm{~cm}^{2}$ tissue culture flasks (Corning Glass Works, Corning, NY) at $37^{\circ} \mathrm{C}$ in a humidified atmosphere of $5 \% \mathrm{CO}_{2}$ for 5 days. PHA was supplied from Wako Pure Chemical Ind. Before the second phase, the number of total floating cells was counted, and then they were treated by the carbonyl iron method (Tebbi et al., 1976) to remove phagocytic cells. After treatment, nonphagocytic cells were recultured in IMDM with $30 \% \mathrm{FCS}, 1 \%$ deionized bovine serum albumin (BSA; Sigma Chemical Co.), $10^{-5} \mathrm{M} 2 \mathrm{ME}, 300 \mu \mathrm{g} / \mathrm{ml}$ iron saturated transferrin (Sigma Chemical Co.), and $2 \mathrm{U} / \mathrm{ml}$ recombinant erythropoietin (Snow Brand Milk Products Co., Tochigi) using six-well tissue culture plates (Coster, Cambridge, MA). The cells were incubated at $37^{\circ} \mathrm{C}$ in a humidified atmosphere containing $5 \% \mathrm{O}_{2}$ and $5 \% \mathrm{CO}_{2}$. Every other day, viable cells were counted by eosin exclusion, and differential counts were made on cytospin preparations stained with Wright-Giemsa stain solution.

Flow cytometry. Fluorescence analyses were performed on a Spectrum III (Ortho Diagnostics Systems Inc., Raritan, NJ) according to the method of Hashimoto et al. (1986). First, about $1 \times 10^{6}$ cells of the erythrocytes, peripheral mononuclear cells or cultured cells were washed twice in a $0.06 \mathrm{M}$ phosphate buffered saline solution, pH 7.3 (PBS), and incubated with $100 \mu$ of the FITC-labeled $V$. villosa, anti-Tn antiserum from the immunized rabbit, or monoclonal anti-A antibody produced in our laboratory at $37^{\circ} \mathrm{C}$ for $30 \mathrm{~min}$. After washing twice in PBS, the erythrocytes incubated with the FITC-labeled lectin were suspended in $100 \mu \mathrm{l}$ of PBS and then analyzed by the Spectrum III. On the other hand, the erythrocytes incubated with the antiserum or monoclonal antibody were reincubated with the FITC-labeled anti-rabbit or -mouse immunoglobulin $(\mathrm{IgG}+\mathrm{M}+\mathrm{A})$ antibody, washed twice in PBS, and then analyzed by the Spectrum III.

\section{RESULTS}

\section{Reactivities of lectins with Tn-erythrocytes}

The patient's erythrocytes were screened with a battery of lectins and found to react strongly with $V$. villosa, $H$. pomotia, and $D$. biflorus, and moderately with $S$. sclarea, but not with $A$. hypogaea. In addition, these erythrocytes were not hemagglutinated by Polybrene or cord sera. These serological findings indicated the presence of the Tn antigen on erythrocytes. 


\section{Production of polyclonal anti-Tn antibody}

Before immunization, antibody activity to all human erythrocytes was found in the rabbit serum. The titers against Tn-negative group $\mathrm{A}, \mathrm{B}, \mathrm{O}$, and Tn-positive group $\mathrm{O}$ erythrocytes were $32,4,1$, and 16 , respectively. After immunization, the titers against $\mathrm{Tn}$-negative and Tn-positive group $\mathrm{O}$ erythrocytes increased to 16 and 128, respectively. Absorption tests demonstrated the activities of anti-A, $-\mathrm{B},-\mathrm{H}$, and $-\mathrm{Tn}$ antibodies in the serum from the immunized rabbit. The anti-Tn antibody was purified through absorption of the rabbit serum with a mixture of group $\mathrm{A}, \mathrm{B}$, and $\mathrm{O}$ erythrocytes. This serum then hemagglutinated only Tn-positive erythrocytes to a titer of 128 . The titer decreased to 8 on $2 \mathrm{ME}$-treatment. The immunoglobulin class of the anti-Tn antibody was determined to be $\operatorname{IgM}$, because its activity was demonstrated in the first peak with a molecular weight of around $900 \mathrm{kDa}$ in HPLC.

\section{Proliferation and differentiation of erythroid progenitors}

In the first phase, mononuclear cells from peripheral blood of a group A healthy volunteer and the patient with $\mathrm{Tn}$ syndrome were cultured in the presence of $5 \%$ PHA-LCM, the numbers of cells increased from $10.2 \times 10^{6}$ to $13.8 \times 10^{6}$ and from $5.8 \times 10^{6}$ to $8.0 \times 10^{6}$, respectively. After removing phagocytic cells, the cultured cells decreased to $6.9 \times 10^{6}$ and $4.8 \times 10^{6}$ cells. In the second phase, cell growth was remarkable; the total numbers of the recultured cells from the volunteer, patient, and a mixture of both rose to $3.3 \times 10^{6}, 2.4 \times 10^{6}$, and $3.7 \times 10^{6} \mathrm{cells} / \mathrm{ml}$ on day 9. The morphological changes on the cultured cells during the second phase of the culture was shown in Fig. 1 and Table 1 . On day $0,99.9 \%$ of the cells were blastic. Erythroid cells increased sequentially day by day in the second phase. Basophilic erythroblasts were detectable on day 3 and orthochromatic erythroblasts and erythrocytes were observed on day 6. On day 9, total erythroid cells in the cultured cells from the volunteer, patient, and their mixture reached $92.0,75.5$, and $59.0 \%$, and mature orthochromatic erythroblasts and denucleated erythrocytes made up $85.1,68.2$, and $50.0 \%$ of these erythroid cells, respectively. Cells containing granules or macrophages were defined as others. Such cells were less than $3.0 \%$ of the total cells during this period. Morphological abnormalities that included the presence of macroerythroblasts, nuclear-cytoplasmic maturation asynchromy, multinuclearity, and abnormal nuclear shape were shown in the erythroid cells of the patient (Fig. 2). These changes indicate the disordered erythropoiesis and are compatible with MDS.

\section{Expression of Tn antigen on erythroid cells}

The Tn antigen on cells were analyzed by flow cytometry using polyclonal antibody and the lectin of $V$. villosa which recognizes only the Tn antigen. In the patient with Tn syndrome, the Tn antigen on the erythrocytes was scored, of which 65.9 and $45.7 \%$ were labeled by the antibody and lectin, respectievly (Fig. 


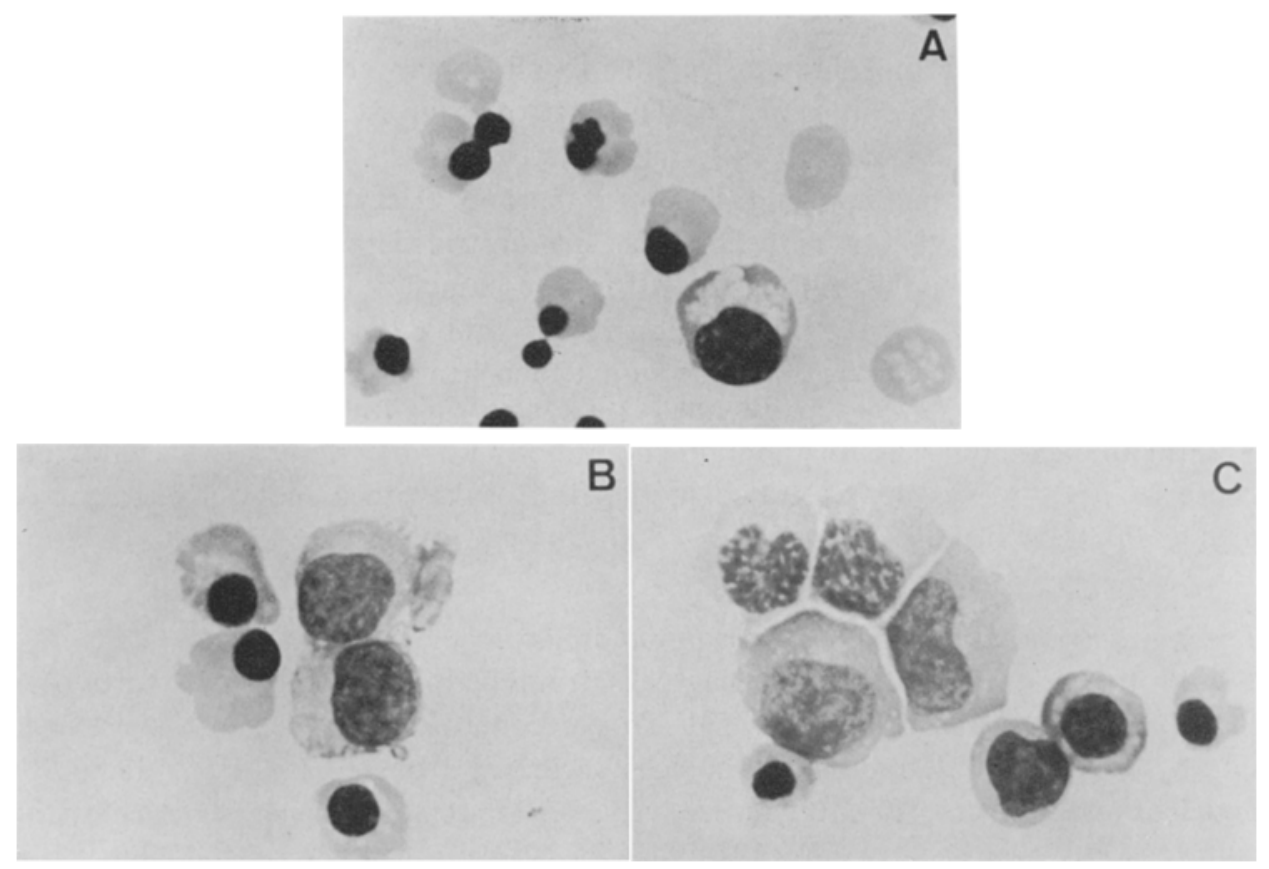

Fig. 1. Morphological changes on cultured cells at day 9 of the second phase of the liquid culture (stained by Wright-Giemsa stain solution). (A) cultured cells from a healthy volunteer; (B) cultured cells from a patient with Tn syndrome; and $(C)$ cultured cells from the mixture of the volunteer's and patient's cells.

Table 1. Morphological changes on the cultured cells derived from 4 healthy volunteers, a patient with Tn syndrome, and their mixture during the second phase of the culture.

\begin{tabular}{|c|c|c|c|c|c|c|c|c|c|}
\hline \multirow{2}{*}{ Differentiation } & \multicolumn{6}{|c|}{ Days of second phase* } & \multicolumn{3}{|c|}{9} \\
\hline & $\mathrm{Na}$ & $\operatorname{Tn} b$ & $M^{c}$ & $\mathrm{~N}$ & $\operatorname{Tn}$ & M & $\mathrm{N}$ & $\operatorname{Tn}$ & $\mathbf{M}$ \\
\hline Blastic cells & $86.5 \pm 3.5$ & 73.0 & & $26.6 \pm 7.4$ & 40.7 & 48.5 & $9.7 \pm 2.9$ & 24.5 & 38.0 \\
\hline Proerythroblasts & $5.5 \pm 1.0$ & 7.0 & & $1.1 \pm 0.2$ & 7.7 & 7.5 & 0.0 & 1. 0 & 3.0 \\
\hline $\begin{array}{l}\text { Basophilic } \\
\text { erythroblasts }\end{array}$ & $8.0 \pm 2.6$ & 18.3 & & $21.8 \pm 1.9$ & 16.7 & 17.0 & $2.2 \pm 1.3$ & 2.0 & 13.0 \\
\hline $\begin{array}{l}\text { Polychromatic } \\
\text { erythroblasts }\end{array}$ & 0.0 & 0.0 & NT d & $36.0 \pm 4.6$ & 29.3 & 23.0 & $11.4 \pm 2.2$ & 21.0 & 13.5 \\
\hline $\begin{array}{c}\text { Orthochromatic } \\
\text { erythroblasts }\end{array}$ & 0.0 & 0.0 & & $9.3 \pm 2.6$ & 5.3 & 0.5 & $51.3 \pm 1.7$ & 39.5 & 24.0 \\
\hline Erythrocytes & 0.0 & 0.0 & & $4.4 \pm 3.1$ & 0.3 & 0.5 & $24.8 \pm 1.6$ & 12.0 & 5.5 \\
\hline Others & 0.0 & 1.7 & & $0.8 \pm 0.4$ & 0.0 & 3.0 & $1.3 \pm 0.0$ & 0.0 & 3.0 \\
\hline
\end{tabular}

* Values are percentage of differential count in each day.

a $\mathrm{N}$, cultured cells from 4 healthy volunteers (mean $\pm \mathrm{SD}$ ); b $\mathrm{Tn}$, cultured cells from a patient with Tn syndrome; $: \mathrm{M}$, cultured cells from the mixture of a healthy volunteer's and patient's cells; d NT, not tested. 


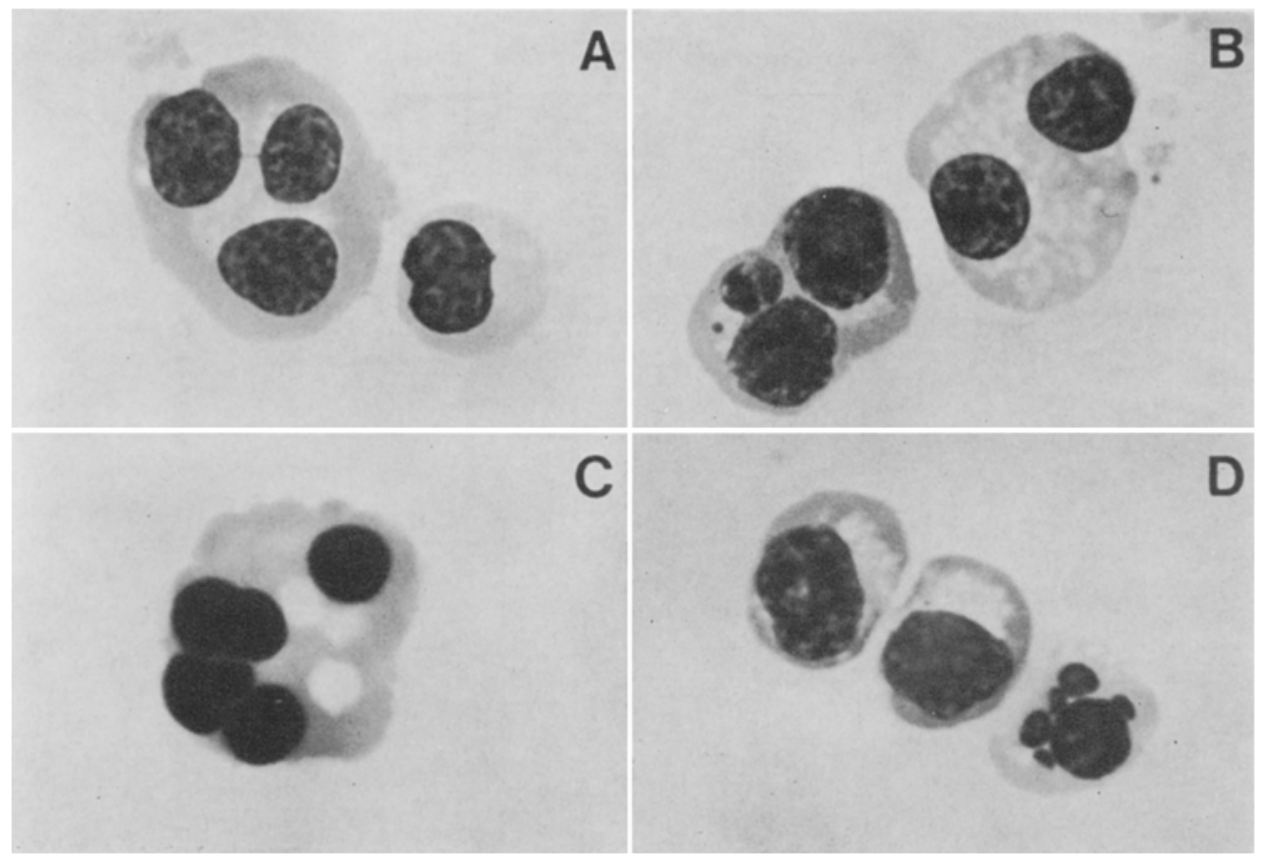

Fig. 2. Abnormal erythroid cells in the cultured cells from the patient with $\mathrm{Tn}$ syndrome at day 9 of the second phase. The abnormalities show megaloblastic changes with multinuclearity (A, B, and C) and nuclear lobes (B and D).

3). In contrast, the erythrocytes from healthy volunteers were entirely negative for the $\mathrm{Tn}$ antigen. The $\mathrm{Tn}$ antigen on the peripheral mononuclear cells from the patient which were prepared for the liquid culture were positive $(41.9 \%)$ as shown in Fig. 3. At the end of the first phase of the culture, the Tn antigen was not detected. Figure 4 summarizes the result obtained in a series ofexperi ments to determine the expression of the Tn antigen on the cells in the second phase of the culture. The Tn expression on the cultured cells obtained from the patient, which was detected by the anti-Tn, increased further during differentiation to mature erythroid series, and $62.7 \%$ of the cells exhibited the Tn antigen on day 9 of the second phase. However, the detection system for the Tn antigen using the lectin of $V$. villosa was not so effective, because the Tn-positive cells were strongly hemagglutinated and reduced by the lectin. During this culture period, Tn-positive cells were not detected on the volunteer's cells. In the culture of the mixture of cells from the patient and volunteer, a population of the Tn-positive cells developed, but the percentage was significantly inhibited $(0.9 \%)$ as shown in Table 2 . On the other hand, on day 9 of the second phase, the group A antigen was expressed on $29.5 \%$ of the cells obtained from the volunteer and $13.5 \%$ of the mixture cells from the volunteer and patient, while it was never detected in the cells from the 

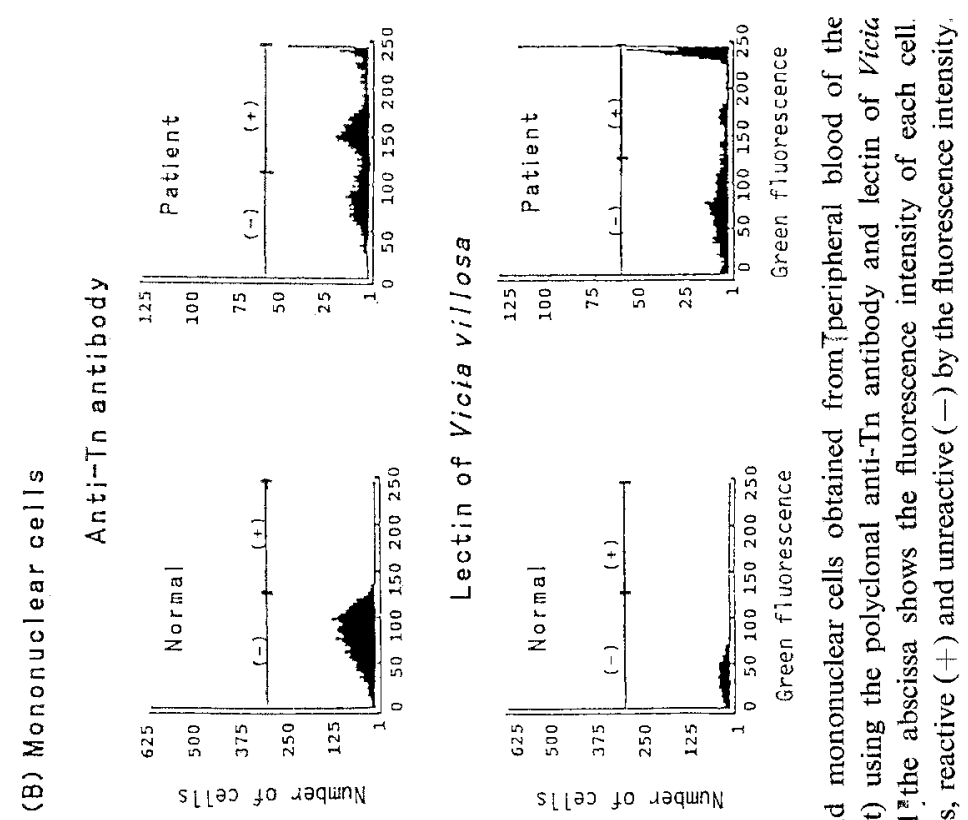

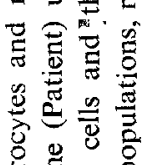

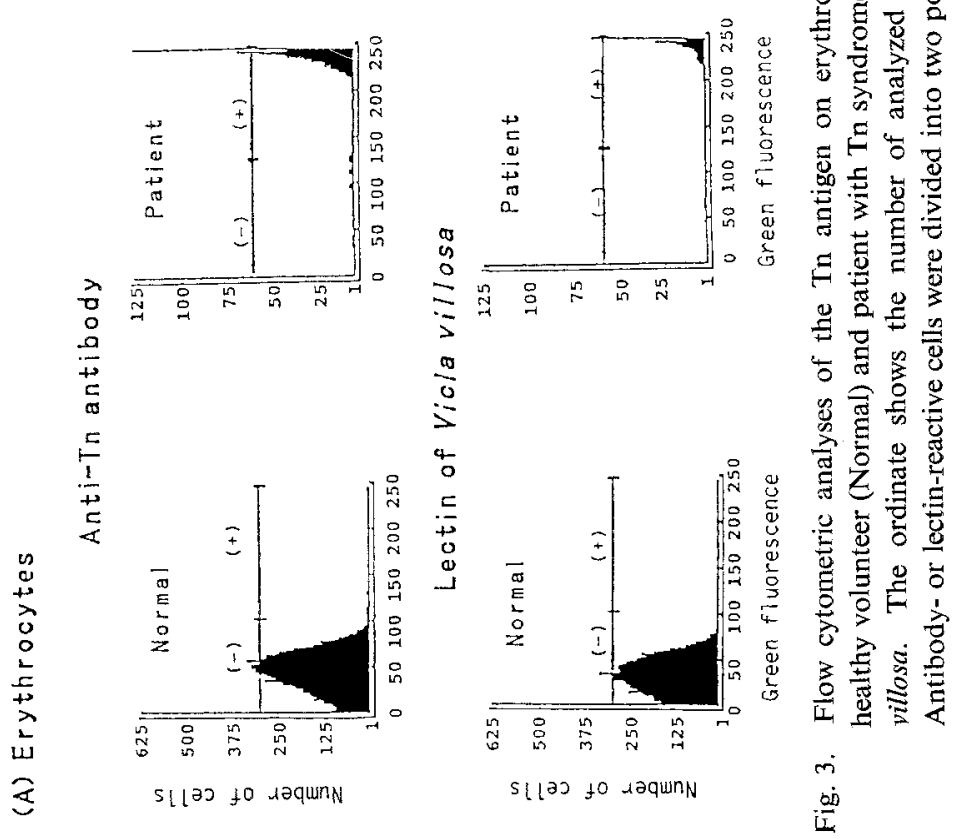


Normal

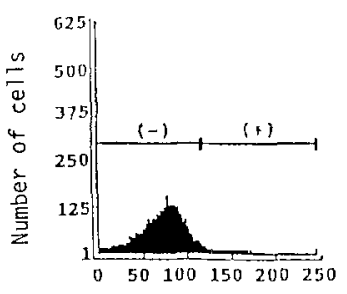

Day 3

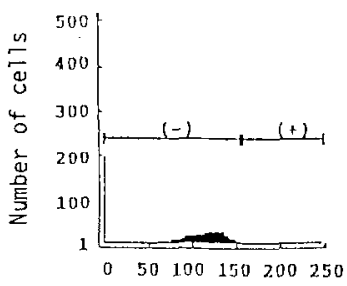

Day 6

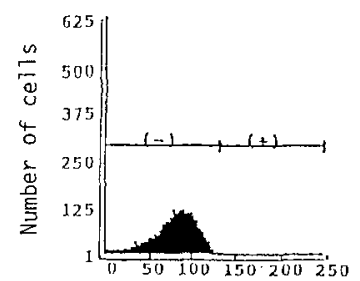

Day 9

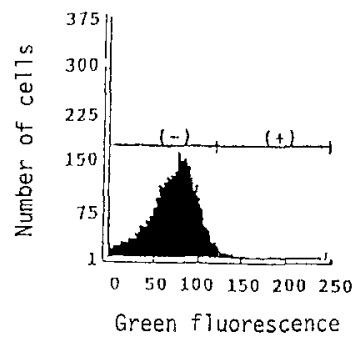

Patient
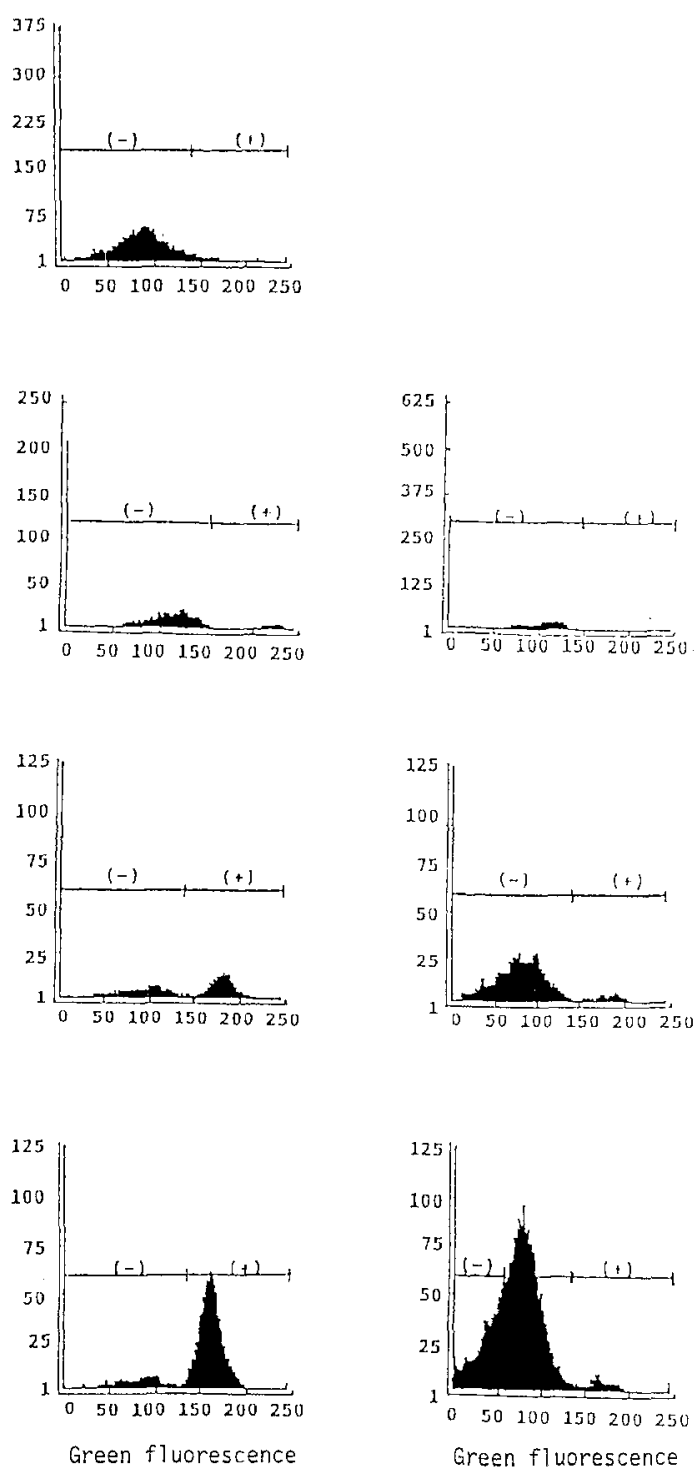

Mixture 
Table 2. Expression of Tn antigen analyzed by the flow cytometry using the anti-Tn antibody.

\begin{tabular}{lccrr}
\hline & \multicolumn{4}{c}{ Days of second phase* } \\
\cline { 2 - 5 } Cultured cells & 0 & 3 & 6 & 9 \\
\hline Normal individual & 0.0 & 0.0 & 0.0 & 0.9 \\
Tn patient & 1.4 & 6.3 & 30.9 & 62.9 \\
Mixture & NT & 1.7 & 2.9 & 0.9 \\
\hline
\end{tabular}

* Values are percentage of Tn-positive cells detected by flow cytometry using the anti-Tn antibody.
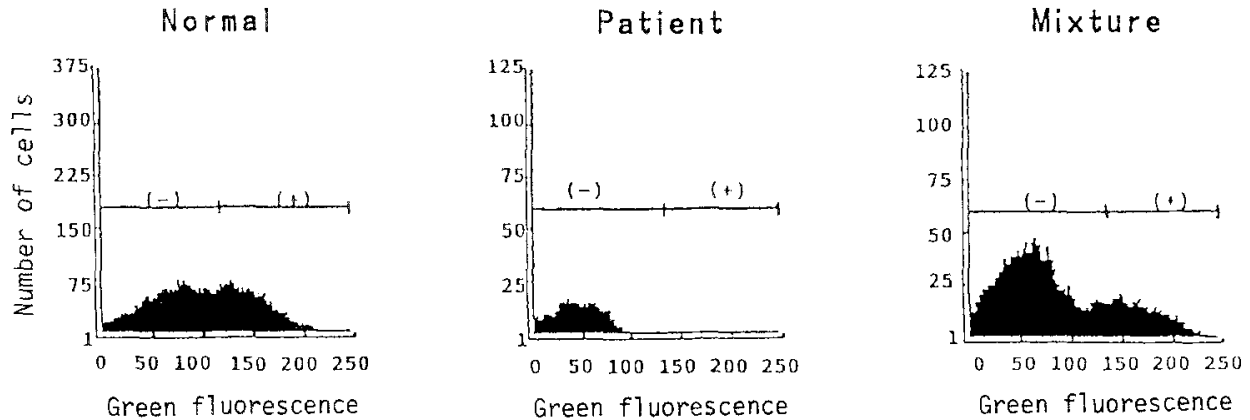

Fig. 5. Flow cytometric analyses of the group A antigen on the cultured cells from the healthy volunteer (Normal), patient with Tn syndrome (Patient), and their mixture (Mixture) using the monoclonal anti-A antibody at day 9 of the second phase of the liquid culture. The ordinate shows the number of analyzed cells and the abscissa shows the fluorescence intensity of each cell. Antibody-reactive cells were divided into two populations, reactive $(+)$ and unreactive $(-)$ by the fluorescence intensity.

patient (Fig. 5). In the mixed culture, the group A antigen developed as might have been expected, while the Tn antigen was suppressed.

\section{DISCUSSION}

The Tn syndrome is characterized by a heterogeneous population of Tn-positive peripheral blood cells that lack the enzyme of $3-\beta$-D-galactosyltransferase, and normal Tn-negative cells (Sturgeon et al., 1973; Cartron et al., 1978b, 1979; Bigbee et al., 1990). The somatic mutation-induced clonal origin of the disorder has been recently reported by the demonstration of Tn-positive and Tn-negative clones derived from burst-forming-unit erythroid (BFU-E), colony-forming-unit eosinophil (CFU-Eo), colony-forming-unit granulocyte/macrophage (CFU-GM), and mixed colony-forming-unit (CFU-GEMM) colonies grown from blood samples obtained from patients with Tn syndrome (Vainchenker et al., 1982, 1985; Brouet et al., 1983; Bigbee et al., 1990). 
In the erythroid series, we have investigated the level of cell differentiation at which the Tn antigen might be expressed. The presence of Tn determinants was explored by the anti-Tn lebeling of erythroid cells derived from peripheral mononuclear cells obtained from a patient with a typical Tn syndrome. A two phase culture system is appropriate for obtaining substantial numbers of erythroid cells of a much more homogeneous population, and therefore it is useful for analyses of the expressions of various membrane components (Wada et al., 1990).

The liquid culture was divided into two phases. At the end of the first phase of the culture, the cultured cells had no detectable expression of the Tn antigen. Tn-positive cells were initially detected on day 3 of the second phase, and increased during erythroid maturation. Serological and biochemical evidence has shown that $\mathrm{N}$-acetyl-D-galactosamine, when covalently bound to erythrocyte surface sialoglycoproteins, glycophorin $\mathrm{A}$ and glycophorin $\mathrm{B}$ by an alkali-labile $\mathrm{O}$ glycosidic linkage, is the chief structural determinant of Tn specificity (Dahr et al., 1974; Vainchenker et al., 1982; Springer and Desai, 1985). Previously we have demonstrated the expression of glycophorin A in erythroid cells on day 3 of the second phase using the liquid culture system (Wada et al., 1990). These data suggest that the expression of glycophorin A and Tn antigens is in parallel.

In the present study, we have demonstrated that the erythroid differentiation was poor in the cultured cells derived from the patient with Tn syndrome. We were interested in exploring the relationships between the expression of $\mathrm{Tn}$ antigens on the erythroid cells and their differentiation. Vainchenker et al. (1985) have put forward a hypothesis that the carbohydrate structure of the Tn antigen may play a crucial role in the regulation of pluripotent stem cells, and the unmasking of this determinant on the Tn-positive clone may be responsible for its proliferative advantage.

In our experiments, the mixed culture of peripheral mononuclear cells from the volunteer and patient suppressed the expression of Tn antigens but did not improve the erythroid differentiation. Accordingly, it is difficult to conclude that erythroid differentiation is directly influenced by the Tn antigen. In addition, this fact suggests that 3- $\beta$-D-galactosyltransferase was secreted by the cultured cells from the volunteer and affected cultured cells from the patient.

Acknowledgments We wish to thank Dr. Juichi Ueki of Department of Internal Medicine, Tottori Prefectural Central Hospital for providing blood samples and Assistant Professor Yoichi Amemiya and Mr. Takeshi Obata of Blood Transfusion Service, Jichi Medical School for flow cytometric analyses. We also thank Mr. Takashi Oyamada and Mr. Toshinori Omi for excellent technical support.

\section{REFERENCES}

Baldwin ML, Barrasso C, Ridolfi RI (1979): Tn-polyagglutinability associated with acute myelomonocytic leukemia. Am J Clin Pathol 72: 1024-1027

Bennett JM, Catovsky D, Daniel MT, Flandri G, Galton DAG, Gralnick HR, Sulton C (1982): Proposals for the classification of the myelodysplastic syndrome. Br J Haematol 51: 189-199 
Bennett JM, Catovsky D, Daniel MT, Flandri G, Galton DAG, Gralnick HR, Sulton C (1985): Proposed revised criteria for the classification of acute myeloid leukemia. Ann Intern Med 103: $620-626$

Bigbee WL, Langlois RG, Stanker LH, Vanderlaan M, Jensen RH (1990): Flow cytometric analysis of erythrocyte population in Tn syndrome blood using monoclonal antibodies to glycophorin A and the Tn antigen. Cytometry 11: 261-271

Bird GWG, Shinton NK, Wingham J (1971): Persistent mixed-field polyagglutination. Br J Haematol 21: 443-453

Bird GWG, Wingham J, Pippard MJ, Hoult JG, Melikian V (1976): Erythrocyte membrane modification in malignant diseases of myeloid and lymphoreticular tissues. Br $J$ Haematol 33: 33: $289-294$

Brouet JC, Vainchenker W, Blanchard D, Testa U, Cartron J-P (1983): The origin of human B and $T$ cells from multipotent stem cells: A study of the Tn syndrome. Eur J Immunol 13: 350352

Cartron J-P, Andreu G, Cartron J, Bird GWG, Salmon C, Gerbal A (1978a): Demonstration of T-transferase deficiency in Tn-polyagglutinable blood samples. Eur J Biochem 92: 111-119

Cartron J-P, Cartron J, Andreu C, Salmon C, Bird GWG (1978b): Selective deficiency of 3- $\beta$-Dgalactosyltransferase (T-transferase) in Tn-polyagglutinable erythrocytes. Lancet i: $856-857$

Cartron J-P, Nurden AT (1979): Galactosyltransferase and membrane glycoprotein abnormality in human platelets from Tn-syndrome donors. Nature 282: 621-623

Dahr W, Uhrenbruck G, Bird GWG (1974): Cryptic A-like receptor sites in human erythrocyte glycoproteins proposed nature of the Tn antigen. Vox Sang 27: 29-42

Fibach E, Manor D, Oppenheim A, Rachmilewitz EA (1989): Proliferation and maturation of human erythroid progenitors in liquid culture. Blood 73: 100-103

Fibach E, Rachmilewitz EA (1990): Proliferation and differentiation of erythroid progenitors in liquid culture: analysis of progenitors derived from patients with polycythemia vera. Am J Hemat 35: 151-156

Hashimoto K, Nakaki Y, Amemiya Y (1986): Flow cytometric analyses for detecting blood group antigens on erythrocytes. Immunohaematology 8: 457-460

Kamesaki T, Kajii E, Ikemoto S (1989): Purification of the demonstrating enzyme from Nepenthes alata against glycophorin $B$ of human red blood cells by high-performance liquid chromatography. J Chromat 489: 384-389

Morrison PL (1983): Red cell antigens and antibodies and their interactions. In: Morrison PL (ed). Blood transfusion in clinical medicine. Blackwell Scientific Publications, Oxford, p 192

Ness PM, Garraty G, Morel PA, Perkins HA (1979): Tn-polyagglutination preceding acute leukemia. Blood 54: 30-34

Springer GF, Desai PR (1985): Tn epitopes, immunoreactive with ordinary anti-Tn antibodies, on normal, desialylated human erythrocytes and on Thomsen-Friedenreich antigen isolated therefrom. Molec Immunol 22: 1303-1310

Sturgeon P, Luner SJ, McQuiston DT (1973): Permanent mixed-field polyagglutinability (PMFP) II. Hematological, biophysical and biochemical observations. Vox Sang 25: 498-512

Suda T, Suda J, Miura Y, Hayashi Y, Eguchi M, Tadokoro K, Saito M (1985): Clonal analysis of basophil differentiation in bone marrow cultures from a Down's syndrome patient with megakaryoblastic leukemia. Blood 66: 1278-1283

Tebbi K, Rubin S, Cowan DH, McCulloch EA (1976): A comparison of granulopoiesis in culture from blood and marrow cells of nonleukemic individuals and patients with acute leukemia. Blood 48: 235-243

Vainchenker W, Testa U, Deschamps JF, Henri A, Titeux M, Breton-Gorius J, Rochant H, Lee D, Cartron J-P (1982): Clonal expression of the Tn antigen in erythroid and granulocyte colonies and its application to determination of the clonality of the human megakaryocyte colony assay. J Clin Invest 69: 1081-1091 
Vainchenker W, Vinci G, Testa U, Henri A, Tabilio A, Fache MP, Rochant H, Cartron J-P (1985): Presence of the $\mathrm{Tn}$ antigens on hematopoietic progenitors from patients with the $\mathrm{Tn}$ syndrome. $\mathrm{J}$ Clin Invest 75 : $541-546$

Wada H, Suda T, Miura Y, Kajii E, Ikemoto S, Yawata Y (1990): Expression of major blood group antigens on human erythroid cells in a two phase liquid culture system. Blood 75: 505-511

Widman FK (1985): Technical Manual, Ed. 9. American Association of Blood Banks. Washington, p 71 